Discussion Paper No. 06-048

An Empirical Analysis of the Effects of Patents and Secrecy on Knowledge Spillovers

Tobias Schmidt

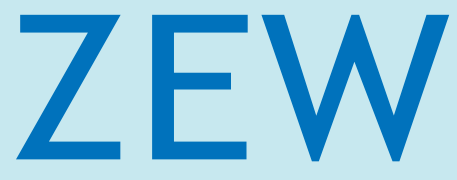

Zentrum für Europäische Wirtschaftsforschung $\mathrm{GmbH}$

Centre for European

Economic Research 
Discussion Paper No. 06-048

\title{
An Empirical Analysis of the Effects of Patents and Secrecy on Knowledge Spillovers
}

\author{
Tobias Schmidt
}

Download this ZEW Discussion Paper from our ftp server:

ftp://ftp.zew.de/pub/zew-docs/dp/dp06048.pdf

Die Discussion Papers dienen einer möglichst schnellen Verbreitung von neueren Forschungsarbeiten des ZEW. Die Beiträge liegen in alleiniger Verantwortung der Autoren und stellen nicht notwendigerweise die Meinung des ZEW dar.

Discussion Papers are intended to make results of ZEW research promptly available to other economists in order to encourage discussion and suggestions for revisions. The authors are solely responsible for the contents which do not necessarily represent the opinion of the ZEW. 


\section{Non-technical summary}

The literature on knowledge spillovers has shown that the need for external knowledge has increased in recent years because technologies and markets are become more and more complex. As firms' innovation activities become more and more dependent on external knowledge, the amount of knowledge available to them becomes a critical factor for innovation and growth.

The amount of freely available knowledge depends on the amount of knowledge generated and the amount of knowledge appropriated by the producers of new knowledge. In this study we will focus on the latter aspect and empirically investigate the impact of the importance of two different methods of knowledge appropriation on the innovation activities of firms. To be more precise, we will analyse the effect of the usage of patent protection and secrecy on knowledge spillovers. Since spillover effects cannot be observed directly, we will look at the results of knowledge spillovers. These results can partially be observed by looking at the innovation activities of firms that (potentially) use external knowledge. We argue that the usage of patents and secrecy should affect the level of spillovers and thus decrease or increase (depending on the method used) the importance of a lack of technological information as a hampering factor for firms' technological innovation processes.

The effect of patents and secrecy on knowledge spillovers is not clear per se. Theoretical considerations suggest that secrecy reduces spillovers almost completely through non-disclosure, while the disclosure requirement of patents generates some knowledge spillovers and at the same time allows firms to appropriate knowledge through legal rights. Empirical research has shown, however, that secrecy is not perfect and some spillovers occur even when firms use secrecy. What is more, some knowledge, such as that embodied in products, cannot be protected by secrecy. It has been argued that firms are no longer using patents to protect knowledge but rather to be able to broker and share knowledge ("Open Innovation approach" Chesbrough, 2003b).

Using firm level data on 3,400 firms from the $4^{\text {th }}$ Community Innovation Survey for Germany we find that both the usage of patents and secrecy decrease knowledge spillovers to other firms in an industry and consequently pose obstacles to their innovation activities. As a result we can conclude that the appropriability effect outweighs the disclosure effect of patents within an industry. We do not find a significant effect of protection methods used in other industries on the lack of information on technologies a firm is faced with. A third result is that the open innovation business model has not been implemented widely. 


\title{
An Empirical Analysis of the Effects of Patents and Secrecy on Knowledge Spillovers
}

\author{
Tobias Schmidt ${ }^{1}$
}

\begin{abstract}
Theoretical considerations suggest that secrecy reduces spillovers almost completely through non-disclosure, while the disclosure requirement of patents generates some spillover and at the same time allows firms to appropriate knowledge. In this paper we empirically analyze whether protection by secrecy or protection by patents is associated with lower knowledge spillovers. Since the amount of knowledge spillovers is hard to measure directly, we look at the impact of the usage of protection methods in an industry on the innovation activities of firms using external knowledge. One goal is to assess if firms have moved to a more open innovation business model, i.e. allow more knowledge spillovers to occur despite using protection methods. Our estimations show that the usage of both, patents and secrecy, hinders the innovation activities of firms through the reduction of spillovers to firms in their own industry. We conclude that the appropriability effect of patents outweighs the disclosure effect. We also find some evidence that the open innovation business model has not been implemented widely.
\end{abstract}

Keywords: Knowledge Spillovers, patents, secrecy, open innovation, ordered probit

The author would like to thank Georg Licht, Dirk Czarnitzki and Katrin Hussinger for their comments. This paper has been presented at the first INIR workshop (2005), 40th Annual Meeting of the Canadian Economic Association (2006), Annual Meeting of the Austrian Economic Association (2006) and the 3rd Augustin Cournot Doctoral Days (2006).

${ }^{1}$ Center for European Economic Research (ZEW), Department of Industrial Economics and International Management, P.O. Box 1034 43, D-68034 Mannheim, Germany, Tel: +49-621-1235235, Fax: +49-621-1235-4235, Email: schmidt@zew.de 


\section{Introduction}

"Open Innovation" is a new way of thinking about the innovation process of firms (Chesbrough, 2003b). Due to significant changes in the competitive and economic environment of firms, closed innovation, i.e. one firm does everything from R\&D to marketing and financing of innovations on its own, are no longer seen as profitable strategies for innovative enterprises. Thus, Chesbrough (2003b) argues that firms have to become more open and reach out to actors beyond their own boundaries to make the most of their inventions and ideas. This includes "knowledge brokering" (Chesbrough, 2003b: 52) and using intellectual property and other appropriability mechanisms to profit from other firms' use of the firm's own knowledge.

The need for external knowledge and other external inputs in the innovation process has also been noted by other authors, like Monjon and Waelbroeck (2003), Peters (2003) or Fagerberg (2005). Fagerberg's (2005) literature review shows that firms' innovation activities rely extensively on external resources. Nooteboom (1999) argues that the need for external knowledge increased because technologies and markets become more and more complex. The need for external knowledge is increasing and more firms are likely to move to an open innovation approach. ${ }^{1}$ The amount of knowledge available in an economy is becoming an important factor for innovation and growth. The amount of freely available knowledge depends on the amount of knowledge generated and the amount of knowledge appropriated by the producers of new knowledge. In this study we will focus on the latter aspect and investigate the impact of the importance of two different appropriability methods on the innovation activities of firms. To be more precise, we will analyse the effect of the usage of patent protection and secrecy in an industry, on knowledge spillovers. Since spillover effects cannot be directly observed, we will lock at the results of these spillovers which can partially be observed, by analysing the innovation activities of firms (potentially) using external knowledge. We argue that the usage of patents and secrecy should affect the level of spillovers and thus decrease or increase (depending on the method used) the importance of a lack of technological information as a hampering factor for firms' technological innovation processes.

The difference between secrecy and patents has been analysed to a great extend in previous studies (see next section). However, few attempts have been made to empirically assess their effect on knowledge spillovers. While secrecy, as the word implies, reduces spillovers through non-disclosure, the effects of patents is less clear. Patents can generate knowledge spillovers through the disclosure requirements laid down in patent laws, but at the same time limit knowledge spillovers by allowing firms developing new knowledge to use it exclusively for a given period of time.

\footnotetext{
${ }^{1}$ Two prominent examples that have adopted a more open innovation strategy are IBM and Microsoft (NY Times, 2005a; NY Times, 2005b)
} 
The difference between formal and strategic protection methods with respect to knowledge spillovers is interesting from a policy point of view. If both groups of protection methods influence the importance of the lack of technological information as an obstacle to innovation with the same order of magnitude and direction, this would be an indication that the patent system doesn't have the desired effect of disclosing valuable and usable knowledge or at least that the firms requiring external knowledge for their innovation activities, can't get access to the relevant knowledge flows. $^{2}$

This dual effect of patents on knowledge spillovers brings us back to the open innovation paradigm:

If open innovation were the business model of an industry and firms would use IP rights to increase the usage of their own knowledge by others, the use of patent protection should not reduce knowledge spillovers and the ability of other firms to get access to the knowledge needed for their innovation activities. Under such a regieme firms would patent their inventions in order to be able to make it available to firms in need of external knowledge, i.e. license it or even give away patented knowledge for free (Chesbrough, 2003b). Because of that, the disclosure and licensing effect of patents should outweigh its appropriability effect and knowledge spillovers should at least not decrease. If patents still lead to a decrease of knowledge spillovers, this may be some indication that the term "open innovation" is rather as an advertising stunt. Firms give the impression that they give away valuable knowledge, but still use it to secure valuable knowledge instead of making it available to others.

An extreme case of open innovation would be "open source". Some times the impression is given by people talking about open innovation, that open innovation is equal to open source, i.e. that all knowledge is readily available to everyone and patent protection is just needed to be able to license new technologies to others and not to inhibit the use of knowledge. We think, however, and will test the assumption, that patents are still used by firms to limit the flow of useful and usable knowledge to external agents. In that sense, our analysis can be seen as an attempt to test one key aspect of the open innovation paradigm, namely the notion that firms use patents not to limit knowledge flows but to increase them.

In the next section we will review the relevant literature on the effect of different legal and strategic protection methods on knowledge flows. Particular attention is given to mechanisms that might explain the gap between the desired effect of protection and the actual effect of protection. To be more precise, we will shed some light on the question why patent protection methods may fail in disclosing useful knowledge and why strategic protection methods like secrecy will not be perfectly efficient in reducing the outflow of knowledge. In section 3 our hypothesis and analytical framework will be described, followed by a section on the data and

\footnotetext{
${ }^{2}$ Note, the lack of information on technology might also be a hampering factor for the innovation activities of firms, because they lack the absorptive capacity to access and use relevant knowledge. In the empirical part, we will try to take this into account.
} 
estimation strategy used. Results will be presented and discussed in section 5, before we conclude.

\section{Related Literature}

In this section we will start with a review of the literature relevant for our analysis of the relationship between different protection methods for innovations, inventions, new knowledge, and knowledge spillovers. Afterwards, a short review of the main features of the "open innovation” paradigm will be provided to enrich our discussion of the topic from the introduction.

\section{Legal Protection vs. Strategic Protection}

Because "rents derive from idiosyncratic knowledge" (Liebeskind, 1997: 623), securing the returns and rents from innovation activities is one of the main concerns of firms developing new products and processes. Moreover, it is in the public interest to make sure that at least some part of the rents can be appropriated by the firm that developed an invention or innovation, in order to set incentives for private R\&D and innovation activities. Put differently, firms wouldn't have an incentive to invest in the development of new knowledge if all the benefits would spill over to their competitors. The well known free rider problem arises because "[...] knowledge is inherently a public good” (Jaffe, 1986: 984; Liebeskind, 1997: 624; Peters, 2003), i.e. it is non-rival in consumption and (partially) non-excludable ${ }^{3}$ (Hanusch and Cantner, 1993; Stiglitz, 1999). Because of the latter feature of knowledge, firms can profit from the inventions of others, either in the form of rent spillovers or knowledge spillovers (Griliches, 1979). However, not all knowledge is available to everyone in an economy for free. There are some factors that hinder the flow of knowledge, e.g. firms might have to invest in R\&D in order to develop the capacity to understand and be able to utilize the knowledge generated by others ("absorptive capacity”), as shown by Cohen and Levinthal (1989; 1990). Another factor is the technological and geographical distance between the firm that produces the knowledge and the firm that wants to use it. ${ }^{4}$

While the absorptive capacity and the distance between two firms reduces the amount of knowledge spilling over because of the set-up of the receiving firm, the firm generating the knowledge can also reduce the flow of knowledge by employing certain protection methods. These protection methods for new knowledge can be

\footnotetext{
${ }^{3}$ Arrow (1962) wrote on this issue "No amount of legal protection can make a thoroughly appropriable commodity of something as intangible as information. The very use of the information in any productive way is bound to reveal it, at least in part. [...] Legally imposed property rights can provide only a partial barrier, since there are obviously enormous difficulties in defining in any sharp way an item of information and differentiating it from similar sounding items." (Arrow, 1962: 615).

${ }^{4}$ An overview of factors moderating the flow of knowledge can be found in Kaiser (2002), Cincera (2005) and Griliches (1992).
} 
placed into two large groups: legal protection methods (such as patents, copyrights and trademarks) and methods that rely on secrecy, complexity of design and fast- or first-mover advantages (hence forth called "strategic protection methods"). ${ }^{5}$ The two famous reports on the Yale survey (Levin et al., 1987) and Carnegie Mellon survey (Cohen et al., 2000) have shown that firms use both methods to protect their intellectual property and their knowledge. These and other studies (e.g. Arundel and Kabla, 1998; Harabi, 1995) also revealed that the importance firms give to legal and strategic mechanisms varies by industry and the type of innovation to be protected. Sometimes an invention is even protected by more than one type of appropriability measure (e.g. Cohen and Walsh, 2000 or Arora, 1997 for an example from the chemical industry). Other factors that influence the choice of the appropriability mechanism and the importance assigned to one or the other mechanism have been put forward: Anton and Yao's (2004) theoretical model shows that the "size" of innovations in terms of cost differentials and pre- and post-innovation market shares plays a role for the choice of appropriability strategy. Arundel's (2001) analysis of data from the Community Innovation Survey (CIS I) reveals that firm size reduces the relative importance of secrecy compared to patents while cooperation in R\&D increases the importance of patents relative to secrecy. König and Licht (1995) find that the amount spent on R\&D and the size of a firm positively influence the number of patent applications. Laursen and Salter (2005) and Liebeskind (1997) argue that the type of knowledge influences the choice of protection methods.

Our focus in this paper is, however, not on the mechanisms that lead firms to use one or the other method or to assign different importance to different measures, but on how the use of different protection methods affects knowledge spillovers. While knowledge disclosure and dissemination is at the core of the legal protection system, strategic protection methods are mostly targeted at preventing knowledge spillovers.

The rationale behind setting up a legal protection system is to grant an inventing firm the right to use their new knowledge exclusively for a given time (Levin et al., 1987) and thus setting incentives for private investment in innovation activities, while at the same time making the new knowledge available to outsiders by requirements to disclose knowledge (see e.g. Gallini, 2002; Markiewicz, 2003). In principle, the patent system is designed to exclude others from using the new invention and particularly the knowledge associated with it, while allowing them to access the new knowledge and learn from it. Legal protection methods provide protection for knowledge that is enforceable in court, but knowledge physically spills over through the text of the patent. As a result firms might see the knowledge published in the patent application as protected ("useless") knowledge rather than a knowledge spillover. ${ }^{7}$ However, the disclosure of (protected) knowledge can also be a source for new ideas for new products or processes and provide information about

\footnotetext{
${ }^{5}$ See e.g. Harabi (1995), Cohen and Walsh (2000), Laursen and Salter (2005)

${ }^{6}$ Arrow, 1962 already noted that the appropriability conditions play an important role for the innovation activities of firms.

${ }^{7}$ As Arrow (1962) noted some (involuntary) spillovers will always occure, because there is no perfect appropriation mechanism for "something so intangible as knowledge" (Arrow, 1962: 615).
} 
the developments of competitors and consequently knowledge spillovers beyond those protected by law. If the protection effect outweighs the disclosure effect, legal protection actually reduces knowledge spillovers rather than fostering them. ${ }^{8}$ This has been argued to be the case by several empirical studies using the importance of legal protection measures as an inverse measure of outgoing spillovers, thus implying that legal protection methods limit outgoing spillovers rather than inducing them (see Bönte and Keilbach, 2005; Cassiman and Veugelers, 2002; Belderbos et al., 2004).

The requirements to disclose (novel) knowledge when using legal protection methods is usually seen as a disincentive for adopting a strategy that is based on legal protection (Laursen and Salter, 2005; Levin et al., 1987; Arora et al., 2005; Arundel and Kabla, 1998; Hussinger, 2004). The reason for this may be that the patent system fails to exclude others from using the disclosed knowledge. The famous Mansfield et al.'s (1981) study shows that $60 \%$ of all patented innovations in their sample were imitated within 4 years.

Then again, Bessen (2005) cites some studies that shows that firms do not assign much value to the information disclosed in patents, raising doubts that significant knowledge spillovers arise from patents. In an early work on the topic Malchup and Penrose (1950) write that "only unconcealable inventions are patented" (Malchup and Penrose, 1950: 27), indirectly saying that the knowledge disclosed in patent applications would also have spilled out through different channels. Cohen et al. (2002) stress that the information disclosed in patents is not very valuable because of the lag between publication of the patent and application for the patent. By the time the patent is published the disclosed knowledge has usually become outdated. Before the patent is in force, the knowledge is rather secret. ${ }^{9}$

Strategic protection methods are used by firms without any legal basis and consequently without any requirements to disclose knowledge. Because of that, "firms that do not wish to disclose information can forgo patenting and use secrecy to protect their investment in innovation" (Arundel, 2001: 612). The effect of strategic protection methods on knowledge flows has been mostly analysed with respect to secrecy. Secrecy is - as the word already implies - the non-disclosure of knowledge. Atallah's (2004) theoretical model is an example that uses this feature of secrecy. In his model the use of secrecy increases the cost of rivals by limiting knowledge spillovers. Empirical models analysing the co-operation decision of firms also assume that strategic protection methods limit outgoing knowledge spillovers (e.g. Belderbos et al., 2004; Cassiman and Veugelers, 2002; Bönte and Keilbach, 2005; Schmidt, 2005b). Strategic protection methods other than secrecy, however, do not (exclusively) rely on keeping knowledge secret, but on being first with the

\footnotetext{
${ }^{8}$ The protection effect can only outweigh the disclosure effect if knowledge spillovers are defined as the disclosure of freely usable knowledge. If they are defined as the disclosure of knowledge in general, patent protection is always increasing knowledge spillovers. We would argue that firms at the receiving end of the knowledge transfer are likely to favour the first definition. Similarly De Bondt (1996) writes "spillvers only refer to the useful part of the information that has been exchanged." (De Bondt, 1996:.4)

${ }^{9}$ Note, this was a peculiarity of the US patent system until 2001, the European Patent Office publishes the patent application a short time after it was received.
} 
introduction of a novel product or process, reaping first mover benefits or by designing an innovation in a complex way that hinders competitors to reengineer them. These help to appropriate the returns of an innovation (Levin et al., 1987), but discloses knowledge. ${ }^{10}$

The view that secrecy decreases knowledge spillovers has been challenged by a number of authors. Liebeskind (1997) shows, that keeping inventions and knowledge secret is very hard and costly. Levin et al. (1987) see a problem for keeping product related knowledge secret, because the product has to be advertised and put into the hands of the customers (and thus potentially also in the hands of their competitors) in order to earn money with it. By putting the product on the market, the knowledge embodied is disclosed and can not be kept secret any longer. ${ }^{11}$ Kultti et al. (2002) state that there will always be some spillovers, even if firms try to keep innovations secret. Their view is indirectly supported by studies that assume that methods to protect inventions and to prohibit knowledge flows, are never perfect.

Secrecy might also be an imperfect method to appropriate knowledge if the knowledge itself is of a specific kind. Cohen and Walsh (2000) for example argue that more generic knowledge makes secrecy "less effective as an appropriability strategy” (Cohen and Walsh, 2000: 10).

\section{What is "Open Innovation" ${ }^{12}$}

“Open innovation” can be defined as "accessing and exploiting outside knowledge while liberating [a firm's] own internal expertise for others' use.” (Chesbrough, 2003a: 12). According to Chesbrough (2003b) firms have to open up because of changes in their competitive environment, like an increased mobility of skilled labor or shorter shelf lifes (product life circles) of technologies. The basic assumption behind the concept is that firms profit from sharing knowledge and ideas with other firms. The opening up includes "knowledge brokering” (Chesbrough, 2003b: 52) and using intellectual property and other appropriability mechanisms to profit from other firms' use of a firm's own knowledge and make their own knowledge and capabilities known to potential partners ${ }^{13}$. The open innovation concept thus sheds a different light on the disclosure component of patents. While the authors cited above have mostly seen the requirement of patents to disclose knowledge as a disincentive for seeking patent protection, Chesbrough suggests that firms should actively use this feature of the system to profit from their own knowledge. The two approaches also propose a different way of thinking about appropriability mechanisms and

\footnotetext{
${ }^{10}$ Some doubts remain whether first-mover advantages are beneficial, because smart followers might imitate the original innovation quite fast. This can of course only be done because knowledge becomes available outside the firms boundaries if a protection method based on lead-time advantages is chosen (see Sofka and Schmidt, 2004 for an overview of first-mover advantages and disadvantages).

${ }^{11}$ One has to distinguish between invention and innovation here. An invention might very well be kept secret until it becomes an innovation, i.e. is introduced into the market (see Arundel, 2001: 613).

${ }^{12}$ This section is entirely based on the seminal work on this topic by Chesbrough (2003b).

${ }^{13}$ Similarly Bureth et al., 2006 and Penin, 2005 argue that patents are used as a coordination device and resolve uncertainty about a firms capabilities and strengths in the co-operation process. They don't specifically make references to the open innovation paradigm, however
} 
knowledge spillovers. While in the open innovation business model patents would be used to increase and manage spillovers to external agents in order to secure profits, the classical view is that appropriability must limit spillovers of useful/important knowledge to competitors to allow firms to reap the benefits of their inventions and innovations.

In contrast to that, the open innovation paradigm, which suggests among other things that firms use the patent system to make their knowledge and capabilities known, can be seen as a strategy where more importance is given to the disclosure effect than the protection effect. Firms may actively use patents as a channel for disseminating knowledge to the outside world and increase the amount of valuable and usable knowledge disclosed through patents.

There is some indication in the literature that open innovation could be simply used as a marketing stunt. As some authors have argued (see above) the knowledge disclosed in the patent applications can be of little value to other firms. Thus a mere increase in patent activities and making patented knowledge available for free by firms advertising themselves as being open, will not necessarily be an indication of a strategy that embraces knowledge sharing more.

\section{Hypotheses}

The hypothesis we derive form the review of the literature are the following:

H1: Patent protection is used to prevent knowledge spillovers. Thus, an increase in the usage of patent protection methods in an industry does increase the perceived importance of the lack of technological knowledge as a hampering factor for innovation ${ }^{14}$.

H2: Protection by secrecy does moderate knowledge spillovers. Thus, an increase in the usage of secrecy in an industry does increase the perceived importance of the lack of technological knowledge as a hampering factor for innovation.

As far as hypothesis 1 is concerned, it is not unlikely that the protection effect might outweigh the disclosure effect since the firm developing an innovation will usually try to reduce the spillovers to others in order to increase their rent, even if they choose patents instead of strategic protection. Since this argument is contrary to the suggestions of the "open innovation" concept, that patents are used to disclose knowledge, hypothesis 1 can be used to analyse the diffusion of the open innovation strategy.

\footnotetext{
${ }^{14}$ The importance of a lack of technological knowledge as a hampering factor for innovation activities will be used in the empirical part as our measure of spillovers or rather the lack of spillovers. For this reason it is included in the hypothesis.
} 


\section{Analytical Framework}

Our focus in this paper is to assess the impact of the usage of different protection methods in a particular industry on the perceived importance of a lack of information on technologies for innovation activities of firms in that industry. Two basic assumptions guide our approach: First, the importance of a lack of technological knowledge is higher (lower) if knowledge spillovers are lower (higher). Second, the level of knowledge spillovers is determined by the protection method used, i.e. patents or secrecy.

The following figure summarizes the empirical model we have in mind. It represents the arguments from the literature that patents and secrecy differ with respect to the disclosure requirements, i.e. that patents have both a disclosure and an appropriability effect while secrecy has only an appropriability effect. We also include the demand for knowledge in the analytical model. It is certainly a factor that influences the importance firms assign to knowledge spillovers. Firms that need a lot of knowledge, because of their size, technology or specific innovation and R\&D activities will be more likely to run into problems with acquiring knowledge for their innovation processes ${ }^{15}$.

\footnotetext{
${ }^{15}$ For some empirical evidence on this issue see the study by Rammer et al., 2005b on SMEs.
} 
Figure 1 Expected effects of different types of protection methods

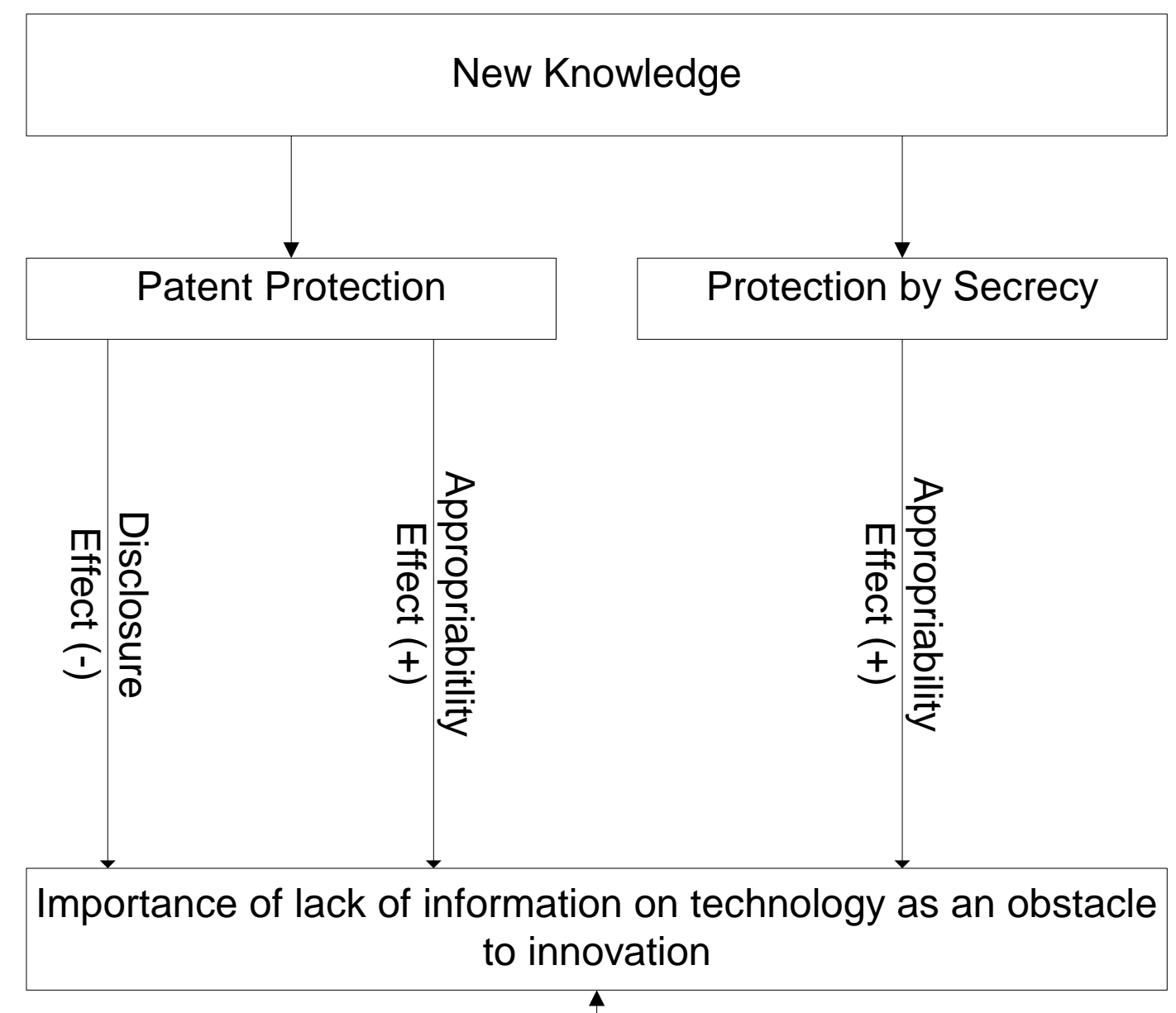

$(+)$

\section{Demand for New Knowledge}

The set-up chosen poses some measurement issues: The first one concerns the measure of knowledge spillovers a firm receives: By looking at obstacles to the innovation activities of firms relying on external knowledge (at the receiving end of the knowledge spillover) we are not able to measure a lack of "actual" spillovers, but rather a lack of "perceived" spillovers. These two types of spillovers are likely to be very different. While the former is a measure of the amount of knowledge in an industry that is not generated or not available, the lack of perceived spillovers, is the amount of knowledge not apprehended (or deemed not accessible) by firms. In our opinion, the lack of perceived spillovers should be higher than the lack of actual spillovers. 
Since the knowledge spillovers we are interested in do not arise within a single firm, but between firms, ${ }^{16}$ we will investigate the impact of the usage of protection methods by firms in an industry (excluding the firm in question) on the importance of the lack of technological knowledge as hampering factor at a given firm. This is not without problems, as the importance of this obstacle to innovation activities will not only be influenced by the use of protection methods but also by certain firm characteristics that are related to the demand for knowledge, the ability to generate knowledge in-house and the firms ability to access external knowledge. The latter is usually referred to as "absorptive capacity" (Cohen and Levinthal, 1989;1990; Daghfous, 2004; Zahra and George, 2000). We will include variables for these three concepts in our estimation model, but obviously cannot control for these aspects in full. In particular the demand for knowledge is hard to measure and can thus only be approximated.

A third issue is that the appropriability and disclosure effect of patents do not coincide in time for a single patent. The appropriability effects sets in when the application is filed ("first to file" rule in European patent law) and the disclosure effect when the application is published (1.5 years after filing). Since we don't analyse single patents but the overall effect of the importance of patents on knowledge spillovers, this problem is mitigates for our study. What is more, we are interested in the overall effect of the usage of patents in an industry during a three year period and not on the effect of a single patent.

\section{Data and Estimation Strategy}

For this study we use firm-level data from the fourth Community Innovation Survey (CIS IV), which was carried out in 2005 and examined innovation activities during the period 2002 - 2004. In Germany, the CIS IV survey was conducted by the Center for European Economic Research (ZEW) and Frauenhofer Institute for System- und Innovationresearch (Fh-ISI) on behalf of the German Federal Ministry of Education and Research (bmbf). It is part of a larger effort to gather data on the innovation behaviour of German firms in industry and services through annual innovation surveys called the Mannheim Innovation Panel (MIP).${ }^{17}$ Even though the survey is conducted annually in Germany and set-up as a panel, we only analyze cross-sectional data, mainly because the questions needed to construct our variables are not included every year. Most other studies using the innovation survey ${ }^{18}$ only use firms with innovation activities. For our study, however, the data needed is

\footnotetext{
${ }^{16}$ This is probably one reason, why according to Laursen and Salter (2005) most studies in this field have been conducted on the industry level.

17 A detailed description of the survey can be found in Janz et al. (2001) and Rammer et al. (2005c). All these surveys use the definitions and concepts of the so called "Oslo Manual" (OECD and Eurostat, 1997).

18 A list of studies conducted with the Mannheim Innovation Panel can be found at http://www.zew.de/de/publikationen/innovationserhebungen/wissaufsaetze.php3
} 
available for almost all firms in the sample, i.e. we analyze about 3,900 firms from industry and services with 5 or more employees.

The independent variable is representing the importance of the lack of information on technology as a hampering factor for innovation (hemm_tech_info). It is directly derived from a question on the hampering factors firms experienced in their innovation activities during the period 2002-2004. In this question firms were asked to rate the importance of 14 different hampering factors on a 4 point-likert scale ranging from 0 (not relevant) to 3 (very important). Because of this natural ordering of the responses to this question, we use the ordered probit procedure, which will be described in more detail below, for estimating our empirical model. It is noteworthy, that the question does not ask specifically for a lack of external information on technology. Assuming that firms which lack technological information internally would either invest in overcoming that lack or try to fill the void by looking for information beyond their own boundaries, we argue that the question mainly captures the external lack of information. We also argue that if they can't invest in overcoming the lack of technological knowledge themselves, they would rather see the lack of finance as a hampering factor, which was also listed in that question, than the lack of information.

The four key explanatory variables - representing the importance of patent protection and protection by secrecy in an industry ${ }^{19}$ - were constructed using a question on the importance of patents, registration of design patterns, industrial designs, trademarks, copyrights, secrecy, complexity of design, and lead-time advantages on competitors: ${ }^{20}$

Patent protection (pat_ind) is represented by the industry (NACE 2) average of the importance of patents for protecting innovations or inventions, rescaled between one (highly important) and zero (not important at all). The same measure is also included at the sector level (manufacturing vs. services) to control for intra-industry spillover effects (pat_sector). ${ }^{21}$

Protection by Secrecy (secr_ind) is constructed as the industry (NACE 2) mean of the importance of secrecy for protecting innovations or inventions, rescaled between one (highly important) and zero (not important at all). The same measure is also

19 To reduce a possible endogeneity, we calculated these two measures for each firm separately, i.e. the industry average was calculated without the firm in question. It thus represents the average over all other firms in the industry.

${ }^{20}$ The question in the German questionnaire differs from the standard CIS IV question on intellectual property rights by not only asking for the usage of different methods, but for the importance of the measure. The question in the German questionnaire was: "During the period 2002-2004 did your enterprise use any of the following intellectual property protection methods? If so: Please indicate the importance of these methods for protecting innovations and inventions of your enterprise.” Each method was rated on a 4 point likert-scale from 0 (not used) to 3 (highly important).

${ }^{21}$ The industry average is calculated for each firm individually by subtracting a firms own evaluation of patents or secrecy from the industry total and dividing this sum by the total number of firms in the industry minus one (see also footnote 19). Similarly, the sector average is calculated by subtracting the industry evaluation (without the firm) form the total in the sector and dividing this sum by the number of firms in all industries but the firms. 
included at the sector level (manufacturing vs. services) to control for intra-industry spillover effects (secr_sector). ${ }^{22}$

As it turns out the industry-level measures of the importance of patent protection and protection by secrecy are highly correlated (Spearman Correlation coefficient: .88), not only at the industry level but also at the level of the individual firm, indicating that firms use both methods together, as already proposed by Cohen and Walsh (2000) and Arora (1997). Because of that, they can not be included in the same regression equation. In order to be able to investigate differences between the effect of patent protection methods and secrecy with respect to knowledge spillovers nonetheless, we calculated the relative importance of patents and secrecy in an industry as the share of enterprises that indicated that secrecy is more important than patents (rel_secr_ind) and the share of enterprises that indicated that patents are more important than secrecy protection (rel_pat_ind) ${ }^{23}$. At the firm level $19 \%$ of all enterprises indicated that secrecy is more important than patent protection, $67 \%$ assigned equal importance and $14 \%$ rated patents as more important.

In addition to these core variables a number of control variables were added at the right hand-side of the model. These variables are meant to control for characteristics and capabilities of a given firm that are assumed to influence its ability to use external sources of knowledge and could thus increase the likelihood that a firm perceives the lack of information on technologies as an obstacle to innovation. To give an example, if a firm has little absorptive capacities, it is usually not able to access and use the knowledge available outside its boundaries, not because knowledge is not there or because it is protected by appropriability mechanisms, but simply because it is unable to understand, assimilate or use it.

Four variables are included to represent the absorptive capacity of a firm (see Daghfous, 2004; Schmidt, 2005a for reviews on the determinants of absorptive capacity). The R\&D intensity (R\&D_int), calculated as the share of R\&D spending of turnover, and the squared R\&D intensity to allow for a non-linear effect (R\&D_int2), a dummy indicating that the firm undertakes R\&D continuously (R\&D_con) ${ }^{24}$, and the share of employees with higher education degrees of total employees (grads). The R\&D related measures also represent firms' ability to generate knowledge in-house through own R\&D and their demand for knowledge, if one assumes that the more $\mathrm{R} \& \mathrm{D}$ a firm does the more knowledge it needs.

The demand for knowledge is also represented by the innovativeness of the firm. In a study on hampering factors for small and medium sized enterprises (SME) Rammer et al. (2005b) report that in 2002 the share of SMEs reporting obstacles to innovation is higher for firms which are more deeply involved in innovation

\footnotetext{
${ }^{22}$ See footnote 21.

${ }^{23}$ In order to control for inter-industry effects the equation used to estimate that model also contains a variable for the importance of patent protection AND secrecy in the sector (manufacturing or services) of the firm (prot_sector).

${ }^{24}$ The R\&D intensity and the variable continuous R\&D was constructed using a question that was only asked for firms which did report innovation activtities. For firms without any innovation activities we set them to zero.
} 
activities. The authors argue that intensively innovating firms are more likely to report the existence of obstacles than less innovative firms because their projects are more complex and they undertake more projects at the same time, which can also be interpreted as a higher demand for knowledge. To control for this we include two dummy variables, one indicating whether the firm has introduced a product innovation that was new to its market (mneu) and one indicating whether the firm has introduced a process innovation (pz) between 2002 and 2004.

As an additional control for the effect that some firms might in general have a higher probability to be (subjectively) more hampered by obstacles to their innovation activities than others our models include a dummy variable that takes the value one if the firm indicates that at least one of the 13 other obstacles to innovation was at least of medium importance (bed_hemm).

The analysis of the data from the Mannheim Innovation panel has revealed that East and West German firms still differ considerable with respect to their innovation activities (see e.g. Rammer et al., 2005a; Sofka and Schmidt, 2004). A dummy variable, which takes the value one if the firm is from the Neue Länder is thus also included in our model (east). In addition to that, two variables for the size of the firm were included, the log of the number of employees (lnempl) and a squared term (lnempl2).

To ensure that the two industry-level variables for the protection methods don't just pick up any industry specific effects, we included three industry group dummies for medium-low-tech manufacturing (NACE 23; 25-28; 351) high-tech manufacturing (NACE 244, 30, 32, 33, 353), and high-tech services (NACE 64, 72, 73), with other manufacturing and services (NACE 10-29 (exc. 244) , 31, 34, 35-37 (excl. 353), $40+41,45,50-52,55,60-63,65-67,70,71,74,75,90,92)$ being the reference group. ${ }^{25}$

The average firm in our sample has about 710 employees. Over $20 \%$ of the employees of these firms are highly educated. More than 30\% of the firms do R\&D continuously and spend on average 3\% of their turnover on R\&D activities. $24 \%$ have introduced product innovations that were new to their market between 2002 and 2004, and $42 \%$ introduced process innovations. Almost half of the firms have experienced the lack of technological information as a hampering factor for their innovation activities, $38 \%$ said it was only somewhat important, about $10 \%$ it was an important hampering factor, and around 1\% indicated it was very important. 32\% of all our enterprises are from East Germany. The share of high-tech manufacturing firms in the sample is $9 \%$ and the share of high-tech services is $7 \%{ }^{26}$

Since the responses to our dependent variable are in natural order from 0 to 3, we will use an ordered probit estimation procedure, which outperforms other models (e.g. multinominal probit and simple OLS) in this case (Greene, 2002, Kennedy,

\footnotetext{
${ }^{25}$ The inclusion of more detailed industry dummies would certainly have benefited our analysis. But most other industry dummies we tried were correlated with other right hand side variables we wanted to keep. Most notably was the correlation between the industry dummies and the variable for continuous R\&D.

${ }^{26}$ A table with additional descriptive statistics can be found in the annex.
} 
1998). The model is similar to the regular binominal model in the sense that the observed variable is assumed to be related to an underlying continuous measure that is unobservable. Because this latent variable can take more than two values (as is the case in the probit model) several parameters or boundary values have to be estimated using a maximum likelihood procedure.

The formal model in our case looks like this:

$$
y^{*}=\beta^{\prime} X+\varepsilon
$$

where $\mathrm{y}^{*}$ is the unobserved variable and $\mathrm{X}$ is the vector of all the independent variables described above. This formula can then be used to estimate the boundary parameters for a change in the dependent variable hemm_tech_info:

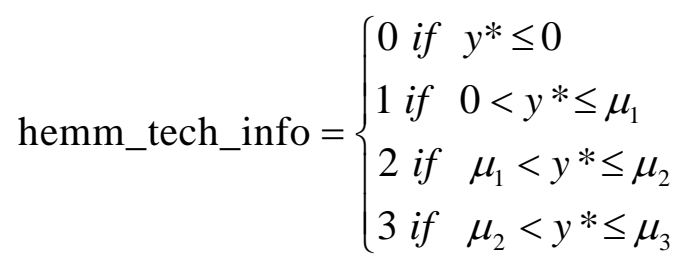




\section{Results}

The results from the ordered probit regressions indicate that both patent protection and protection through secrecy increase the perceived lack of information on technology as a hampering factor for innovation activities significantly. ${ }^{27}$ However, only the industry-level variables are significant. This indicates that the use of protection methods by other firms from a firm's own industry hampers its innovation activities more than the use of protection methods by firms in other industries. Consequently, hypothesis 1 and 2 can only be confirmed for the industry-level of protection. Furthermore, the estimations suggest, that the appropriability effect of patents outweighs the disclosure effect in an industry. If this were not the case, the coefficient on patent protection should have been either negative or not significant, as is the case for the importance of patent protection in all industries in a firm's sector beside its own. Since both coefficients for the industry-level measure, that for patent protection and that for secrecy are positive and significant there is evidence that they both reduce knowledge spillovers, i.e. the amount of valuable and usable knowledge available to others in an industry. Both mechanisms can be seen as a way to hinder the innovation activities of competitors and other firms in the same industry and appropriate the returns from inventions and innovations through limiting the availability of useful knowledge outside ones own boundaries. Due to the high correlation between the secrecy and patent variable they can not be included separately in a single equation. In order to test whether the effect of patents is significantly different from secrecy, we estimate the effect of the share of firms in an industry indicating that patents are more important than secrecy and the share of firms indicating the opposite is true on our dependent variable. The results in the last column (3) of Table 1 show that both variables are not significant, providing further evidence that both protection methods influence the innovation activities of firms similarly. ${ }^{28}$

The insignificance of the sector-level variables is surprising. One interpretation of this result is that firms' innovation activities rely more on knowledge from a firms own industry and less on knowledge from other industries. Then again, some empirical studies have found intra-industry spillovers of particular relevance for firms' innovation behavior and innovation performance (e.g. Inkmann, 2000; Steurs, 1995). An alternative explanation is more technical, maybe our measure of protection at the sector level is too broadly defined and should rather than include all industries outside a firms own industry only include industries with which the firm is closely related, e.g. through input-output relations or similar technologies. A third explanation is that firms protect knowledge that is only relevant for the innovation activities of a firm in the same industry, but not for firms in other industries.

\footnotetext{
${ }^{27}$ To test the robustness of the results, we ran the same regressions with slightly modified measures for patent protection and secrecy. We used two dummies indicating if the respective appropriability mechanisms were at least of medium importance. In both cases the results didn't change.

${ }^{28}$ Joint significance of the two variables could also be rejected.
} 
Table 1: Regression results of ordered probit estimations (dependent variable: importance of lack of information on technologies as an obstacle to innovation)

\begin{tabular}{|c|c|c|c|}
\hline & $(1)$ & $(2)$ & (3) \\
\hline \multirow[t]{2}{*}{ Importance of patent protection (industry level) } & $0.261^{\star \star}$ & & \\
\hline & $(0.149)$ & & \\
\hline \multirow[t]{2}{*}{ Importance of patent protection (sector level) } & 0.134 & & \\
\hline & $(0.236)$ & & \\
\hline \multirow[t]{2}{*}{ Importance of protection by secrecy (industry level) } & & $0.349 * *$ & \\
\hline & & $(0.176)$ & \\
\hline \multirow[t]{2}{*}{ Importance of protection by secrecy (sector level) } & & 0.208 & \\
\hline & & $(0.396)$ & \\
\hline \multirow[t]{2}{*}{$\begin{array}{l}\text { Share of firms indicating that patents > secrecy } \\
\text { (industry level) }\end{array}$} & & & 0.289 \\
\hline & & & $(0.496)$ \\
\hline \multirow[t]{2}{*}{\begin{tabular}{|l}
$\begin{array}{l}\text { Share of firms indicating that secrecy }>\text { patents } \\
\text { (industry level) }\end{array}$ \\
\end{tabular}} & & & 0.706 \\
\hline & & & $(0.434)$ \\
\hline \multirow[t]{2}{*}{$\begin{array}{l}\text { Importance of protection by secrecy + patents } \\
\text { (sector level) }\end{array}$} & & & 0.177 \\
\hline & & & $(0.298)$ \\
\hline \multirow[t]{2}{*}{ Share of employees with higher education degree in $\%$} & $-0.003^{* \star *}$ & $-0.003^{\star \star \star}$ & $-0.003^{\star \star *}$ \\
\hline & $(0.001)$ & $(0.001)$ & $(0.001)$ \\
\hline \multirow{2}{*}{ R\&D intensity } & 0.174 & 0.176 & 0.245 \\
\hline & $(0.268)$ & $(0.266)$ & $(0.266)$ \\
\hline \multirow[t]{2}{*}{ R\&D intensity, squared } & -0.069 & -0.068 & -0.084 \\
\hline & $(0.105)$ & $(0.104)$ & $(0.106)$ \\
\hline \multirow[t]{2}{*}{ Continuous in-house R\&D } & $-0.096^{*}$ & $-0.099 *$ & $-0.090^{*}$ \\
\hline & $(0.055)$ & $(0.055)$ & $(0.054)$ \\
\hline \multirow[t]{2}{*}{ Importance of other hampering factors } & $3.186^{\star \star \star}$ & $3.184^{\star \star \star}$ & $3.184^{\star * *}$ \\
\hline & $(0.315)$ & $(0.315)$ & $(0.315)$ \\
\hline \multirow[t]{2}{*}{ Market novelty (dummy) } & 0.004 & 0.003 & 0.006 \\
\hline & $(0.052)$ & $(0.052)$ & $(0.052)$ \\
\hline \multirow[t]{2}{*}{ Process Innovation (dummy) } & $0.114^{\star \star \star}$ & $0.113^{\star \star \star}$ & $0.110^{\star \star \star}$ \\
\hline & $(0.040)$ & $(0.040)$ & $(0.040)$ \\
\hline \multirow[t]{2}{*}{ Number of employees, log } & 0.055 & 0.054 & 0.053 \\
\hline & $(0.047)$ & $(0.047)$ & $(0.047)$ \\
\hline \multirow[t]{2}{*}{ Number of employees, log, squared } & -0.006 & -0.006 & -0.005 \\
\hline & $(0.004)$ & $(0.004)$ & $(0.004)$ \\
\hline \multirow[t]{2}{*}{ East Germany (dummy) } & $-0.159^{* * *}$ & $-0.156^{\star \star \star}$ & $-0.155^{\star \star \star}$ \\
\hline & $(0.048)$ & $(0.048)$ & $(0.048)$ \\
\hline Industry Groups (dummy) & YES & YES & YES \\
\hline Observations & 3,403 & 3,403 & 3,403 \\
\hline Loglikelihood & -3019.98 & -3019.64 & -3020.05 \\
\hline
\end{tabular}

* significant at 10\%; ** significant at 5\%; *** significant at 1\%; Robust Standard Errors in parentheses

Our control variables offer some interesting insights as well. Only one of the proxies for absorptive capacity is highly significant and has the expected sign. The more absorptive capacity a firms has in the form of highly educated employees the 
less likely it is that this firm perceives the lack of information on technologies as an obstacle to innovation, i.e. the more likely it is to receive knowledge spillovers. The negative and slightly significant coefficient of the continuous in-house $R \& D$ activities provides further evidence that higher absorptive capacity, increases the ability to access knowledge and thus mitigates the problem of a lack of information on technology.

The lack of significance for the R\&D intensity variables can be explained by differing effects of $\mathrm{R} \& \mathrm{D}$ on absorptive capacity and the demand for knowledge. $\mathrm{R} \& \mathrm{D}$ is not only conducted in order to build absorptive capacities, which would decrease the importance of the obstacle, but also to generate innovations. If firms invest heavily in the development of innovations, their knowledge requirements are higher if they invest only a small fraction of their turnover in R\&D. At the same time their own research generates ideas and opens their mind to technological opportunities, for which additional knowledge is required. These new projects are likely to be more of an explorative nature, which require more complex and not readily available knowledge than exploitive projects. As a result of the higher knowledge requirements the likelihood that these firms run into the problem of a lack of technological innovation is higher as well. To summarize this point, firms with a larger share of R\&D expenditure per turnover, see a whole range of technological opportunities and thus perceive the lack of information to be more relevant than firms which have a low share and as a result a more narrow field of view with respect to technological opportunities. These "perception" effects clearly works in the opposite direction as the effects of absorptive capacity on knowledge spillovers discussed in the previous sections and as our results for R\&D activities suggest, cancel each other out (partially). For continuous R\&D activities the same arguments can be brought forward. Our estimation results suggest, however, that for continuous $\mathrm{R} \& \mathrm{D}$ activities the effect on absorptive capacity is stronger than the perception effect.

The variable for other obstacles (bed_hemm) is highly significant, indicating that the obstacles to innovation are highly related to each other. We think that the inclusion of this variable controls for this baseline effect.

Process innovators are significantly more hampered in their innovation activities than non-innovators, while innovators with market novelties are not. This is surprising, since usually it is assumed that process innovations are based on internal knowledge and learning by doing while product innovations and in particular market novelties require more external knowledge. Our results suggest the opposite, however

Size matters for the perception of the importance of information on technologies as an obstacle to innovation, as expected. However, the relationship between size and the obstacle is not a linear one, but is inverse U-shaped. The turning point is between firms with 90 and 200 employees. For smaller firms it might be a less important obstacle, because they just follow a small number of (innovation) projects at the same time (Rammer et al., 2005b) or focus on technologies where they have all the knowledge required to bring inventions to markets. They rather lack the marketing 
knowledge and financial means to introduce innovations. Large firms, on the opposite, have many projects going on at the same time and require lots of knowledge. They nonetheless assign less importance to the lack of information as medium sized firms. A reason for this might be that they have the capability, resources and established channels to gather the external knowledge needed in their innovation processes and are thus not hindered as much in their innovation activities as medium-sized firms.

Finally, East German firms assign a lower importance to the lack of information on technology, than West German firms. The difference is only marginally significant and only in two out of three equations, however. The difference might stem from the fact that East German firms are more likely to adopt a follower strategy in their innovation activities (see Sofka and Schmidt, 2004). If they rely on a follower strategy the lack of information becomes less of a problem, because all the information required for imitating a new product or process has to be available before it can be imitated. Their strategy is more one of exploiting available knowledge instead of exploring new opportunities. As a result they adopt a more narrow innovation approach and decreases the amount of external knowledge required.

\section{Conclusion}

In this paper we study the influence of the usage of patent protection and protection by secrecy in an industry on knowledge spillovers. Since knowledge spillovers can not be measured directly we investigate the effects of protection on the lack of knowledge spillovers, i.e. technological knowledge. We treat the two appropriability mechanisms separately, because their basic set-up is quite different, while patents have a build-in requirement to disclose knowledge and provide a legal basis for the protection of knowledge, secrecy relies on non-disclosure, but is not defendable in court. Our findings indicate that both patents and secrecy decrease knowledge spillovers to other firms in an industry and consequently pose obstacles to their innovation activities. Because of that we can conclude, that the appropriability effect outweighs the disclosure effect of patents within an industry. We do not find a significant effect of protection methods used in other industries on the lack of information on technologies a firm is faced with.

Since the protection or appropriability effect of patents outweighs the disclosure effect within an industry, we can conclude that the open innovation business model has not been implemented in the industries we investigate to an extent that it shows up in our data. The insignificance of the sector-level variables for protection methods supports this hypothesis. The open innovation paradigm suggests that the management of IP rights and the use of patents should increase knowledge flows to external partners rather than hinder them. However, the results obtained from the 
ordered probit models indicate that the majority of firms didn't use patent protection between 2002 and 2004 to make their knowledge freely available. On the contrary, firms used patents to protect knowledge from usage by other firms in their industry. Then again, maybe firms tried to be more open, but the firms requiring the external knowledge didn't get the impression that they can easily get access to the knowledge on technology made available. Future studies should thus try to consider both sides of the knowledge spillovers in empirical studies on open innovation. What is more, we only analyzed one aspect of the open innovation paradigm. The investigation of the licensing behavior of firms would certainly enrich our understanding of the situation and might lead to a different conclusion. If firms use patents to initially reduce knowledge flows but than license all patents to external partners, this could well be considered open innovation.

The descriptive statistics as well as the regression results provide clear evidence that we are not in a world of "open source innovation", i.e. all new knowledge is made available. Not only are both types of protection methods used to reduce knowledge flows, they are also assigned equal importance by almost all firms. Note, the open innovation paradigm doesn't proposes this extreme form of open innovation.

Some suggestions for future research are the following:

The analysis could be enriched by including additional legal or strategic protection methods, like lead-time advantages or copyrights. Their expected effect on spillovers is less clear. Copyrights, for example, provide legal rights to a whole document or product, not necessarily to the knowledge transferred. To give an example from our own profession: You cannot copy a section form a copyrighted article directly, but you can use the main idea of the article as the starting point for your studies.

To our knowledge this study is one of the first to investigate the prevalence of open innovation empirically. The discussion of the open innovation paradigm would certainly profit from further empirical studies on the usage of IP to transfer knowledge and the role of appropriability in the open innovation concept in general.

This paper is based on data from the fourth Community Innovation Survey (CIS). Similar surveys were conducted in all member states of the European Union in 2005, using the harmonized Eurostat questionnaire and methodology. It would certainly be of interested to compare our findings with those of other countries, taking into account the differences in the intellectual property systems in the respective country. Questions like those used for the construction of the variables in our study, have also been included in previous CIS surveys, opening up the opportunity to asses developments over time. 


\section{Annex}

Table 1: Variables included in the model

\begin{tabular}{|c|c|c|}
\hline Variable & Type & ConstI \\
\hline Hemm_tech_info & ordered & $\begin{array}{l}\text { Variable that takes a value between } 0 \text { and } 1 \text { according to the } \\
\text { following scheme: The lack of information on technology as } \\
\text { an obstacle to innovation was not relevant (0), of minor } \\
\text { importance (1), important (2), or very important (3). }\end{array}$ \\
\hline Pat_ind & & $\begin{array}{l}\text { Importance of patent protection as a method to protect } \\
\text { inventions and innovations, rescaled between } 0 \text { (not used) to } \\
1 \text { (highly important). Calculated at the industry level } \\
\text { excluding the firm in question. }\end{array}$ \\
\hline Pat_sector & & $\begin{array}{l}\text { Importance of patent protection as a method to protect } \\
\text { inventions and innovations, rescaled between } 0 \text { (not used) to } \\
1 \text { (highly important). Calculated at the sector level } \\
\text { excluding the industry of the firm in question. }\end{array}$ \\
\hline Secr_ind & & $\begin{array}{l}\text { Importance of secrecy as a method to protect inventions and } \\
\text { innovations, rescaled between } 0 \text { (not used) to } 1 \text { (highly } \\
\text { important). Calculated at the industry level excluding the } \\
\text { firm in question. }\end{array}$ \\
\hline Secr_s & & $\begin{array}{l}\text { Importance of secrecy as a method to protect inventions and } \\
\text { innovations, rescaled between } 0 \text { (not used) to } 1 \text { (highly } \\
\text { important). Calculated at the sector level excluding the } \\
\text { industry of the firm in question. }\end{array}$ \\
\hline Prot_sector & & $\begin{array}{l}\text { Importance of secrecy and patents as a method to protect } \\
\text { inventions and innovations, rescaled between } 0 \text { (not used) to } \\
1 \text { (highly important). Calculated at the sector level } \\
\text { excluding the industry of the firm in question. }\end{array}$ \\
\hline Rel_secr_ind & & $\begin{array}{l}\text { Share of firms indicating that secrecy is more important than } \\
\text { patents (industry level) }\end{array}$ \\
\hline Rel_pat_ind & & $\begin{array}{l}\text { Share of firms indicating that patents are more important } \\
\text { than secrecy (industry level) }\end{array}$ \\
\hline Grads & $\%$ & $\begin{array}{l}\text { Share of employees with higher education in total } \\
\text { employees. }\end{array}$ \\
\hline R\&D_int & $\%$ & $\begin{array}{l}\text { Share of R\&D expenditure in turnover, } 2004 \\
\text { (Zero for firms without innovation activities) }\end{array}$ \\
\hline R\&D_int2 & $\%$ & $\begin{array}{l}\text { Share of R\&D expenditure in turnover, 2004, squared } \\
\text { (Zero for firms without innovation activities) }\end{array}$ \\
\hline R\&Dcon & Dummy & One, if firm was engaged in R\&D activities continuously \\
\hline bed_hemm & Dum & $\begin{array}{l}\text { One, if firm perceived at least one of } 13 \text { obstacles to } \\
\text { innovation as medium important. }\end{array}$ \\
\hline
\end{tabular}




\begin{tabular}{|l|l|l|}
\hline Variable & Type & Construction \\
\hline mneu & Dummy & $\begin{array}{l}\text { One, if the firm introduced at least one product innovation } \\
\text { that was new to its market between 2002 and 2004. }\end{array}$ \\
\hline pz & Dummy & $\begin{array}{l}\text { One, if the firm introduced at least one process innovation } \\
\text { between 2002 and 2004. }\end{array}$ \\
\hline Lnempl & Log & Natural logarithm of number of employees in 2004 \\
\hline Lnempl2 & Log & Natural logarithm of number of employees in 2004, squared \\
\hline east & Dummy & One, if a firm is located in Eastern Germany. \\
\hline bres_1 & Dummy & One, if a firm is from medium-low-tech manufacturing \\
\hline bres_1 & Dummy & One, if a firm is from high-tech manufacturing. \\
\hline bres_2 & Dummy & One, if a firm is from high-tech services. \\
\hline
\end{tabular}

Table 2: Industries included

\begin{tabular}{|l|l|l|}
\hline Name & Label & NACE \\
\hline $\begin{array}{l}\text { Other manufacturing and } \\
\text { services }\end{array}$ & bres_0 & $\begin{array}{l}10-22 ; 24 \text { (excl. 244); 29; 31; 34- } \\
\text { 37 (excl. 353); 40-41; 45; 50-52; } \\
60-67 ; 70-74 ; 90 ; 92\end{array}$ \\
\hline $\begin{array}{l}\text { Medium-low-tech } \\
\text { manufactring }\end{array}$ & bres_1 & $23 ; 25-28 ; 351$ \\
\hline High-tech manufacturing & bres_2 & $244 ; 30 ; 32 ; 33 ; 353$ \\
\hline High-tech services & bres_3 & $64 ; 72 ; 73$ \\
\hline
\end{tabular}

Table 3: Descriptive Statistics I

\begin{tabular}{|l|c|c|}
\hline $\begin{array}{l}\text { lack of information on } \\
\text { technologies is }\end{array}$ & number of observations & percentage \\
\hline very important & 64 & $1.9 \%$ \\
\hline important & 360 & $10.6 \%$ \\
\hline somewhat important & 1,304 & $38.3 \%$ \\
\hline not relevant & 1,675 & $49.2 \%$ \\
\hline
\end{tabular}


Table 4: Descriptive Statistics II

\begin{tabular}{|c|c|c|c|c|}
\hline & Mean & Mean & Mean & t-value \\
\hline & Sample & $\begin{array}{c}\text { Firms without } \\
\text { lack of } \\
\text { information } \\
\text { on } \\
\text { technologies } \\
\end{array}$ & \begin{tabular}{|c|} 
Firms with \\
lack \\
of information \\
on \\
technologies \\
\end{tabular} & $\begin{array}{c}\text { T-Test for } \\
\text { mean } \\
\text { difference }\end{array}$ \\
\hline Observations & 3,403 & 1,675 & 1,728 & \\
\hline$\%$ of total & - & $49.2 \%$ & $50.8 \%$ & \\
\hline \multirow[t]{2}{*}{ Importance of patent protection (industry level) } & 0.188 & 0.165 & 0.210 & -7.553 \\
\hline & $(0.173)$ & $(0.167)$ & $(0.177)$ & \\
\hline \multirow[t]{2}{*}{ Importance of strategic protection (industry level) } & 0.291 & 0.268 & 0.313 & -7.963 \\
\hline & $(0.165)$ & $(0.161)$ & $(0.166)$ & \\
\hline \multirow{2}{*}{ Importance of patent protection (sector level) } & 0.185 & 0.181 & 0.188 & -2.038 \\
\hline & $(0.100)$ & $(0.096)$ & $(0.099)$ & \\
\hline \multirow[t]{2}{*}{ Importance of strategic protection (sector level) } & 0.286 & 0.285 & 0.287 & -1.353 \\
\hline & $(0.058)$ & $(0.057)$ & $(0.059)$ & \\
\hline \multirow[t]{2}{*}{\begin{tabular}{|l|} 
Share of firms indicating that \\
secrecy $>$ patents (industry level)
\end{tabular}} & 0.178 & 0.169 & 0.186 & $-6,844$ \\
\hline & $(0.072)$ & $(0.073)$ & $(0.072)$ & \\
\hline \multirow[t]{2}{*}{\begin{tabular}{|l} 
Share of firms indicating that \\
patents > secrecy (industry level)
\end{tabular}} & 0.178 & 0.175 & 0.180 & $-3,304$ \\
\hline & $(0.049)$ & $(0.049)$ & $(0.049)$ & \\
\hline \multirow[t]{2}{*}{ Share of employees with higher education. in \% } & 20.500 & 20.565 & 20.436 & 0.159 \\
\hline & $(23.638)$ & $(24.066)$ & $(23.223)$ & \\
\hline \multirow[t]{2}{*}{ R\&D intensity } & 0.033 & 0.026 & 0.040 & -3.127 \\
\hline & $(0.126)$ & $(0.106)$ & $(0.143)$ & \\
\hline \multirow[t]{2}{*}{ Continuous R\&D (dummy) } & 0.315 & 0.266 & 0.363 & -6.176 \\
\hline & $(0.465)$ & $(0.442)$ & $(0.481)$ & \\
\hline \multirow[t]{2}{*}{ Importance of other hampering factors (dummy) } & 0.833 & 0.661 & 0.999 & -29.221 \\
\hline & $(0.373)$ & $(0.474)$ & $(0.024)$ & \\
\hline \multirow[t]{2}{*}{ Market novelty (dummy) } & 0.243 & 0.193 & 0.292 & -6.778 \\
\hline & $(0.429)$ & $(0.395)$ & $(0.455)$ & \\
\hline \multirow[t]{2}{*}{\begin{tabular}{|l} 
Process Innovator (dummy) \\
\end{tabular}} & 0.422 & 0.348 & 0.494 & -7.680 \\
\hline & $(0.558)$ & $(0.547)$ & $(0.559)$ & \\
\hline \multirow[t]{2}{*}{ Number of Employees } & 710.304 & 607.238 & 810.208 & -0.874 \\
\hline & $(6787.111)$ & $(6283.552)$ & $(7242.315)$ & \\
\hline \multirow[t]{2}{*}{ East Germany (dummy) } & 0.325 & 0.357 & 0.293 & 3.967 \\
\hline & $(0.468)$ & $(0.479)$ & $(0.455)$ & \\
\hline \multirow[t]{2}{*}{ Medium-low-tech manufacturing } & 0.142 & 0.122 & 0.161 & -3.226 \\
\hline & $(0.349)$ & $(0.328)$ & $(0.368)$ & \\
\hline \multirow[t]{2}{*}{ High-tech manufacturing } & 0.088 & 0.066 & 0.109 & -4.461 \\
\hline & $(0.284)$ & $(0.249)$ & $(0.312)$ & \\
\hline \multirow[t]{2}{*}{ High-tech services } & 0.074 & 0.072 & 0.075 & -0.334 \\
\hline & $(0.261)$ & $(0.259)$ & $(0.264)$ & \\
\hline
\end{tabular}


Table 5: Coefficients of ordered probit estimations (dependent variable: importance of lack of information on technologies as an obstacle to innovation)

\begin{tabular}{|c|c|c|c|}
\hline & $(1)$ & $(2)$ & (3) \\
\hline \multirow{2}{*}{ Importance of patent protection (industry level) } & $0.261^{\star \star}$ & & \\
\hline & $(0.149)$ & & \\
\hline \multirow[t]{2}{*}{ Importance of patent protection (sector level) } & 0.134 & & \\
\hline & $(0.236)$ & & \\
\hline \multirow[t]{2}{*}{ Importance of protection by secrecy (industry level) } & & $0.349^{* \star}$ & \\
\hline & & $(0.176)$ & \\
\hline \multirow[t]{2}{*}{ Importance of protection by secrecy (sector level) } & & 0.208 & \\
\hline & & $(0.396)$ & \\
\hline \multirow[t]{2}{*}{ Share of firms indicating that patents > secrecy (industry level) } & & & 0.289 \\
\hline & & & $(0.496)$ \\
\hline \multirow[t]{2}{*}{ Share of firms indicating that secrecy > patents (industry level) } & & & 0.706 \\
\hline & & & $(0.434)$ \\
\hline \multirow[t]{2}{*}{ Importance of protection by secrecy + patents (sector level) } & & & 0.177 \\
\hline & & & $(0.298)$ \\
\hline \multirow[t]{2}{*}{ Share of employees with higher education degree in $\%$} & $-0.003^{\star * *}$ & $-0.003^{\star \star \star}$ & $-0.003^{\star \star \star}$ \\
\hline & $(0.001)$ & $(0.001)$ & $(0.001)$ \\
\hline \multirow[t]{2}{*}{ R\&D intensity } & 0.174 & 0.176 & 0.245 \\
\hline & $(0.268)$ & $(0.266)$ & $(0.266)$ \\
\hline \multirow[t]{2}{*}{ R\&D intensity, squared } & -0.069 & -0.068 & -0.084 \\
\hline & $(0.105)$ & $(0.104)$ & $(0.106)$ \\
\hline \multirow[t]{2}{*}{ Continuous in-house R\&D } & $-0.096^{*}$ & $-0.099^{*}$ & $-0.090^{\star}$ \\
\hline & $(0.055)$ & $(0.055)$ & $(0.054)$ \\
\hline \multirow[t]{2}{*}{ Importance of other hampering factors } & $3.186^{\star \star \star}$ & $3.184^{\star \star \star}$ & $3.184^{\star \star \star}$ \\
\hline & $(0.315)$ & $(0.315)$ & $(0.315)$ \\
\hline \multirow[t]{2}{*}{ Market novelty (dummy) } & 0.004 & 0.003 & 0.006 \\
\hline & $(0.052)$ & $(0.052)$ & $(0.052)$ \\
\hline \multirow[t]{2}{*}{ Process Innovation (dummy) } & $0.114^{\star \star \star}$ & $0.113^{\star \star *}$ & $0.110^{\star \star *}$ \\
\hline & $(0.040)$ & $(0.040)$ & $(0.040)$ \\
\hline \multirow[t]{2}{*}{ Number of employees, log } & 0.055 & 0.054 & 0.053 \\
\hline & $(0.047)$ & $(0.047)$ & $(0.047)$ \\
\hline \multirow[t]{2}{*}{ Number of employees, log, squared } & -0.006 & -0.006 & -0.005 \\
\hline & $(0.004)$ & $(0.004)$ & $(0.004)$ \\
\hline \multirow{2}{*}{ East Germany (dummy) } & $-0.159 * \star *$ & $-0.156^{\star \star \star}$ & $-0.155^{\star \star *}$ \\
\hline & $(0.048)$ & $(0.048)$ & $(0.048)$ \\
\hline \multirow[t]{2}{*}{ Medium-low-tech manufacturing } & $0.114^{\star}$ & $0.114^{\star}$ & $0.109^{*}$ \\
\hline & $(0.061)$ & $(0.061)$ & $(0.062)$ \\
\hline \multirow[t]{2}{*}{ High-tech manufacturing } & 0.096 & 0.065 & 0.064 \\
\hline & $(0.075)$ & $(0.081)$ & $(0.085)$ \\
\hline \multirow[t]{2}{*}{ High-tech Services } & 0.052 & 0.006 & -0.014 \\
\hline & $(0.093)$ & $(0.098)$ & $(0.117)$ \\
\hline Observations & 3,403 & 3,403 & 3,403 \\
\hline McKelvey and Zavoina Pseudo R2 & 0.595 & 0.595 & 0.595 \\
\hline$x^{\wedge} 2$ & 150.99 & 151.80 & 151.86 \\
\hline Loglikelihood & -3019.98 & -3019.64 & -3020.05 \\
\hline
\end{tabular}

* significant at 10\%; ** significant at 5\%; ${ }^{* * *}$ significant at 1\%; Robust Standard Errors in parentheses 


\section{References}

Anton, J.J. and D.A. Yao (2004), Little Patents and Big Secrets: Managing Intellectual Property, RAND Journal of Economics 35 (1), 1-22.

Arora, A. (1997), Patent, Licensing, and Market Structure in Chemicals, Research Policy 26, 391-403.

Arora, A., M. Ceccagnoli and W.M. Cohen (2005), R\&D and the Patent Premium, NBER Working Paper No. 9431

Arrow, K.J. (1962), Economic Welfare and the Allocation of Resources for Invention, in: Nelson, R. R. (ed.), The Rate and Direction of Inventive Activity, Economic and Social Factors, NBER Special Conference Series, Princeton, USA.

Arundel, A. (2001), The relative effectiveness of patents and secrecy for appropriation, Research Policy 30 (4), 611-624.

Arundel, A. and I. Kabla (1998), What percentage of innovations are patented? Empirical estimates for European firms, Research Policy 27, 127-141.

Atallah, G. (2004), The Protection of Innovations, CIRANO Scientific Series No. 2, Montréal.

Belderbos, R., M. Carree, B. Diederen, B. Lokshin and R. Veugelers (2004), Heterogeneity in R\&D cooperation strategies, International Journal of Industrial Organization 22 (8-9), 1237-1263.

Bessen, J. (2005), Patents and the Diffusion of Technological Information, Economic Letters 86 (1), 121-128.

Bönte, W. and M. Keilbach (2005), Concubinage or Marriage? Informal and Formal Cooperations for Innovation, International Journal of Industrial Organization 23 (3-4), 279-302.

Bureth, A., R. Levy, J. Penin and S. Wolff (2006), Strategic Reasons for Patenting: Between exclusion and coordination rationales, Revista die Politica Economica, forthcoming.

Cassiman, B. and R. Veugelers (2002), R\&D Cooperation and spillovers: Some empirical evidence from Belgium, American Economic Review 44 (3), 11691184.

Chesbrough, H.W. (2003a), A Better Way to Innovate, Harvard Business Review 81 (7), 12-13.

Chesbrough, H.W. (2003b), Open Innovation - The New Imperative for Creating and Profiting from Technology, Harvard Business School Press, Boston, USA.

Cincera, M. (2005), Firms' productivity growth and R\&D spillovers: An analysis of alternative technological proximity measures, CEPR Discussion Paper No. 4894, London. 
Cohen, W.M., A. Goto, A. Nagata, R.R. Nelson and J.P. Walsh (2002), R\&D Spillovers, Patents and Incentives to Innovate in Japan and the United States, Research Policy 313 (8-9), 1349-1367.

Cohen, W.M. and D.A. Levinthal (1989), Innovation and Learning: The two faces of R\&D, Economic Journal 99 (397), 569.

Cohen, W.M. and D.A. Levinthal (1990), Absorptive capacity: A new perspective on learning and innovation, Administrative Science Quarterly 35 (1), 128.

Cohen, W.M., R.R. Nelson and J.P. Walsh (2000), Protecting Their Intellectual Assets: Appropriability Conditions and Why U.S. Manufacturing Firms Patent (or Not), NBER Working Paper No. 7552

Cohen, W.M. and J.P. Walsh (2000), R\&D spillovers, appropriability and $R \& D$ intensity: a survey based approach, Economic Assessment Office.

Daghfous, A. (2004), Absorptive Capacity and the Implementation of KnowledgeIntensive Best Practices, SAM Advanced Management Journal 69 (2), 21-27.

De Bondt, R. (1996), Spillovers and innovation activities, International Journal of Industrial Organization 15, 1-28.

Fagerberg, J. (2005), Innovation: A Guide to the Literature, in: Fagerberg, J., D. Mowery and R. Nelson (eds.), The Oxford Handbook of Innovation, Oxford University Press, Oxford.

Gallini, N.T. (2002), The Economics of Patents: Lessons from Recent U.S. Patent Reform, Journal of Economic Perspectives 16 (2), 131-155.

Greene, W.H. (2002), Econometric Analysis, Prentice Hall, New York.

Griliches, Z. (1979), Issues in assessing the contribution of research and development to productivity growth, Bell Journal of Economics 10 (1), 92116.

Griliches, Z. (1992), The Search for R\&D Spillovers, Scandinavian Journal of Economics 94 (Supplement), 29-47.

Hanusch, H. and U. Cantner (1993), Neuere Ansätze der Innovationstheorie und der Theorie des technischen Wanndels - Konsequenzen für eine Industrie- und Technologiepolitik., in: Meyer-Krahmer, F. (ed.), Innovationsökonomie und Technologiepolitik - Forschungsansätze und politische Konsequenzen., Physica Verlag, Heidelberg, 11-46.

Harabi, N. (1995), Appropriability of technological innovations - An empirical analysis, Research Policy 24, 981-992.

Hussinger, K. (2004), Is Silence Golden? Patents versus Secrecy at the Firm Level, ZEW Discussion Paper No. 04-78, Mannheim.

Inkmann, J. (2000), Horizontal and Vertical R\&D Cooperation, CoFE-Discussion Paper No. 00-02, Konstanz.

Jaffe, A.B. (1986), Technological Opportunity and Spillovers of R\&D: Evidence from Firm's Patent, Profits, and Market Value., American Economic Review 76 (5), 984-1001. 
Kaiser, U. (2002), Measuring Knowledge Spillovers in Manufacturing and Services: An Empirical Assessment of Alternative Approaches, Research Policy 31 (1), $125-44$.

Kennedy, P. (1998), A Guide to Econometrics, MIT Press, Cambridge, USA.

König, H. and G. Licht (1995), Patents, R\&D and Innovation, Evidence from the Mannheim Innovation Panel, ifo Studien 41, 521-543.

Kultti, K., T. Takalo and J. Toikka (2002), Secrecy vs. Patenting, University of Helsinki Working Paper, Helsinki.

Laursen, K. and A. Salter (2005), My Precious - The Role of Appropriability Strategies in Shaping Innovation Performance, DRUID Working Paper No. 05-02, Frederiksberg, Denmark.

Levin, R.C., A.K. Klevorick, R.R. Nelson and S.G. Winter (1987), Appropriating the Returns from Industrial Research and Developement, Brookings Paper on Economic Activity No. 3, Washington.

Liebeskind, J.P. (1997), Keeping Organizational Secrets: Protective Institutional Mechanisms and their Costs, Industrial and Corporate Change 6 (3), 623663.

Malchup, F. and E. Penrose (1950), The Patent Controversy in the Nineteenth Century, The Journal of Economic History 10 (1), 1-29.

Mansfield, E., M. Schwartz and S. Wagner (1981), Imitation Costs And Patents: An Empirical Study, The Economic Journal 91, 907-918.

Markiewicz, K.R. (2003), University Patenting and the Rate of Knowledge Exploitation, Academy of Management Best Papers and Proceedings, August 2003, Seattle, USA.

Monjon, S. and P. Waelbroeck (2003), Assessing Spillovers from Universities to firms: Evidence from French firm-level data, International Journal of Industrial Organization 21 (9), 1255-1270.

Nooteboom, B. (1999), Innovation. learing and industrial organisation, Cambridge Journal of Economics 23, 127-150.

NY Times (2005a), I.B.M. hopes to Profit by Making Patents Available Free, New York Times Online, Issue: 04/11/05.

NY Times (2005b), Microsoft to Lease Some Ideas to Strat-Ups, New York Times Online, Issue: 05/05/2005.

OECD and Eurostat (1997), Oslo Manual- Proposed Guidelines for Collecting and Interpreting Technological Innovation Data, OECD/Eurostat, Paris.

Penin, J. (2005), Patents versus ex post rewards: A new look, Research Policy 34, 641-656.

Peters, M.A. (2003), Education Policy in the Age of Knowledge Capitalism, Policy Futures in Education 1 (2), 361-380. 
Rammer, C., B. Aschhoff, T. Doherr, B. Peters and T. Schmidt (2005a), Innovationsverhalten der deutschen Wirtschaft - Indikatorenbericht zur Innovationserhebung 2004, ZEW / Infas, Mannheim.

Rammer, C., E. Müller, D. Heger, B. Aschhoff, V. Zimmermann and F. Reize (2005b), Innovationspotentiale und -hemmnisse unterschiedlicher Gruppen von KMU., Schwerpunktstudie zur technologischen Leistungsfähigkeit Deutschlands im Auftrag des bmb+f, ZEW Mannheim and KFWBankengruppe, Mannheim and Frankfurt/Main.

Rammer, C., B. Peters, T. Schmidt, B. Aschhoff, T. Doherr and H. Niggemann (2005c), Innovationen in Deutschland - Ergebnisse der Innovationserhebung 2003 in der deutschen Wirtschaft, ZEW Wirtschaftsanalysen Band 78, Nomos Verlagsgesellschaft, Baden-Baden.

Schmidt, T. (2005a), Absorptive Capacity - One Size Fits All? A Firm-level Analysis of Absorptive Capacity for Different Kinds of Knowledge, ZEW Discussion Paper No. 05-72, Mannheim.

Schmidt, T. (2005b), Knowledge Flows and R\&D Co-operation: Firm-Level Evidence from Germany, ZEW Discussion Paper No. 5-22, Mannheim.

Sofka, W. and T. Schmidt (2004), I Like the Way you Move - An Empirical Investigation into the Mechanisms Behind First Mover and Follower Strategies, ZEW Discussion Paper No. 04-87, Mannheim.

Steurs, G. (1995), Inter-Industry R\&D spillovers: What difference do they make?, International Journal of Industrial Organization 13, 249-276.

Stiglitz, J.E. (1999), Knowledge as a Global Public Good, in: Stern, M. A. (ed.), Global Public Goods, Oxford University Press, Oxford, NY, 308-325.

Zahra, S.A. and G. George (2000), Absorptive capacity: a review and reconceptualization, Academy of Management Proceedings, 1. 